\title{
Po co dramaturgowi aktor performatywny?
}

\begin{abstract}
Wojciech Baluch, Po co dramaturgowi aktor performatywny? [Why a playwright needs a performative actor?]. „Przestrzenie Teorii” 36. Poznań 2021, Adam Mickiewicz University Press, pp. 137-152. ISSN 1644-6763. DOI 10.14746/pt.2021.36.8.

The article is an attempt to answer the question of how contemporary performative acting enters into artistically and cognitively significant interactions with the new Polish dramaturgy. The relationship between the two forms of art is discussed in relation to two types of acting: task-oriented and performative. The concept of both types of acting is derived from the analysis of selected contemporary theater and television productions of dramas and scenarios arising from the achievements of the latest Polish dramaturgy. The examples that are analyzed reveal various aspects and types of the actors' performative game, which include the issues of the actor's subjectivity, their presence on stage and the materiality of the body. Unlike many of today's discussions, the interpretations and comments on selected scenes and fragments of a performance do not focus on the subversive dimension of the above-mentioned aspects of acting, but look for new perspectives of reception and, at the same time, broaden the areas of theatrical experience. These new perspectives and areas are triggered by references to the affective and mental processes of reception, which allow perceptions to exclude, at least partially, the tendency to automatically interpret everything that surrounds them. The analyses featured in the article therefore aim to describe those aspects of performative acting that enable the viewer to derive benefit from what the new Polish dramaturgy offers.
\end{abstract}

KEYWORDS: dramaturgy, performative acting, affectiveness

Pytanie podobne do postawionego w tytule powinienem w zasadzie powtórzyć w autoodniesieniu do moich własnych dociekań, jakie do tej pory prowadziłem nad dramaturgia. O ile bowiem w kilku napisanych przeze mnie tekstach, w których starałem się zbliżyć od różnych stron do zjawiska współczesnej dramaturgii, moje rozważania oscylowały wokół osoby dramaturga, o tyle próby dookreślenia, kim właściwie jest dramaturg, obejmowały pytania o jego funkcję w procesie twórczym, miejsce w instytucji teatru (w tym w zespole teatralnym), wreszcie o sposoby czy techniki pracy. Interesujace mnie zagadnienia pozostawały zatem transcendentne wobec samej osoby dramaturga jako żywego podmiotu biorącego udział w pracy twórczej. W przypadku aktora sprawa wygląda nieco inaczej. Wprawdzie i o aktorze można mówić, opisując różnorodne techniki gry, jego miejsce we wspólnocie, jaka wytwarza się na styku widowni i sceny, czy też rozważając jego status ontologiczny. Niezależnie jednak od naszych zainteresowań czy też bliskich nam metod naukowego poznania, w przypadku aktora nie sposób usunaćc z horyzontu naszych wyobrażeń jego psychofizycznej obecności. Pomimo bowiem tego, że wiele nurtów teoretyzowania dążyło do oczyszczenia wzor- 
ców lub procedur mówienia o sztuce ze stawiającej opór materialności, żywa obecność na scenie aktora bodaj najsilniej krzyżowała plany tych projektów, które dążyły do redukcji jego potencjału twórczego do dyskursywnych opisów lub modeli systematyzujących wymiary sztuki aktorskiej.

Jednak moje zainteresowanie aktorem oraz materialnościa jego obecności na scenie nie jest podyktowane potencjałem oporu sztuki aktorskiej wobec wciąż dominujących nurtów konstruktywistycznych czy też sprawczością materii, która stanowi popularny przedmiot rozważań współczesnej filozofii. Żywa obecność aktora na scenie wydaje mi się ciekawa ze względu na jej zdolność do wzbudzania naszych aktywności poznawczych w obszarach do tej pory przed nami zakrytych lub słabo rozpoznanych. Postrzegane z tej perspektywy aktorstwo staje się zatem praktyką filozofowania. O taki rodzaj humanistycznego teoretyzowania apeluje część dzisiejszych myślicieli. Interesujące mnie aktorstwo performatywne nie jest jednak prostym wcieleniem postulatu, który rozważania i spekulacje intelektualne chciałby zastapić lub przynajmniej uzupełnić o działania praktyczne. Rola, która powstaje na scenie teatralnej za sprawa aktora performatywnego, to zazwyczaj po części wynik wcześniejszych wspólnych przemyśleń i ustaleń dokonywanych na próbach. Jeśli więc nie jest w pełni reprezentacja, to chociaż w pewnym stopniu stanowi refleks tego, co zostało wcześniej przepracowane i zatwierdzone jako element znaczący. Mogłoby się zatem wydawać, że aktor performatywny stanowi syntezę aktorstwa, którego wiodącą funkcja jest reprezentacja, oraz tych praktyk, które starając się uwolnić od teatralnej sztuki przedstawiania, główny nacisk kładą na obecność aktora, ustanawianą za sprawa samego działania, a zatem procesu. Aktorstwa performatywnego nie sposób jednak sprowadzić do sumy dwóch antynomii. Stanowi ono bowiem raczej zbiór różnorodnych praktyk, które eksplorują wcześniejsze metody gry, a zarazem sposoby performatywnej obecności, dokonując ciagłego przegrupowania ich elementów. W tym sensie aktorstwo performatywne nie jest metodą, ale raczej postawą twórczą oraz pewną zdolnością do ciagłego penetrowania swoich możliwości i zakresu gry aktorskiej.

Czemu jednak taki rodzaj sztuki nazywam aktorstwem performatywnym? Wybór tego akurat określenia można tłumaczyć dwoma desygnatami, do których ono odsyła. Słowo „aktor” kojarzy się z tradycyjnym teatrem, natomiast określenie „performatywny” kieruje uwagę w stronę szerokiego zakresu performatywności w sztuce, codziennym życiu, a także perspektywach badawczych. Określenie „aktor performatywny” nie zostało jednak stworzone jako kompilacja twórczych praktyk i poznawczych aktywności. Zaczerpnąłem je z żargonu twórców teatralnych, którym zdarza się przeciwstawiać aktora performatywnego aktorowi zadaniowemu. Ta dość banalna opozycja może wydawać się mało znacząca w kontekście przedstawionych 
powyżej bardziej złożonych wstępnych propozycji wyjaśnienia tego, co rozumiem pod pojęciem ,aktora performatywnego”. Jednak celem, do którego zmierzam, nie jest ostateczne zdefiniowanie tego, czym jest aktorstwo performatywne, lecz rozpoznanie jego potencjału sprawczego poprzez przyjrzenie się zarówno sposobom jego używania, jak i praktykom aktorskim.

Zacznę więc od anegdoty filmowej, którą wybieram jako punkt wyjścia do próby zobrazowania tego, jak można pojmować aktorstwo performatywne i zadaniowe. Ta anegdota obejmuje wycinek historii opowiedzianej w serialu Artyści, wyreżyserowanym przez Monikę Strzępkę na podstawie scenariusza Pawła Demirskiego. Zawarta w ośmiu odcinkach fabuła przedstawia historię, której dwa główne wątki stanowią: intryga władz miasta próbujących doprowadzić do zamknięcia miejskiego Teatru Popularnego i przemienienia go w przynoszący zyski budynek komercyjny oraz próby przetrwania teatru pod wodzą nowego dyrektora, które z coraz większą świadomością zagrożenia podejmuja pracownicy teatru, w tym aktorzy. Przedsiębrane przez dyrektora starania stworzenia ambitnego repertuaru nie przynoszą jednak oczekiwanego rezultatu. Ostatnią deską ratunku wydaje się propozycja przygotowania premiery przez słynną reżyser Marię Richter. Niekwestionowany autorytet reżyserki światowej sławy wywołuje euforię w zespole aktorskim, którego członkowie marzą o pracy z tak wybitną artystka. Realizacja marzeń poszczególnych członków zespołu aktorskiego nie jest jednak ani prosta, ani oczywista. Przekonuje się o tym między innymi najbardziej uznany aktor teatru Jerzy. Podczas przesłuchania nie spełnia oczekiwań Richter, która w słowach pełnych szacunku dla jego sztuki aktorskiej rezygnuje ze współpracy z nim w planowanej sztuce. Ostatecznie nie dowiemy się, czego od aktorów oczekuje najsławniejsza polska reżyserka. A może reżyser? Bo przecież nietrudno się domyślić, że Richter to pastiszowy portret Krystiana Lupy. Wspominam o tym powiązaniu fikcyjnej postaci z realnym polskim reżyserem, ponieważ pozwala ono spojrzeć na oczekiwania Richter przez pryzmat aktorów Lupy, o których bodaj najczęściej mówi się, że są aktorami performatywnymi. Czego zatem brakuje Jerzemu, aby wejść do zespołu „performatywnych"? To chyba jednak źle postawione pytanie w stosunku do czołowego aktora wymyślonego przez Demirskiego Teatru Popularnego. Wspaniały kunszt aktorski, jakim dysponuje Jerzy, nie przejawia bowiem braków, ale raczej nadmiar możliwości, które jest w stanie zaoferować. Jerzy jest typowym aktorem zadaniowym, co sugeruje nam klarownie jedna z końcowych scen drugiej linii rozwoju akcji, związanej z próbami zamknięcia teatru przez władze miasta. Wskutek zbiegu okoliczności aktorzy zdobywają komórkę warszawskiego radnego, dzięki czemu dowiadują się, że osobą stojąca za planem zamknięcia teatru jest prezydent miasta, który lobbuje na rzecz jednej z firm deweloperskich. Sama wiedza nie wystarcza jednak do 
tego, aby udowodnić winę polityka. Dlatego korzystają z umiejętności zdobytych w zawodzie i przygotowuja prowokację. Jej wykonawca jest nie kto inny jak Jerzy, który korzysta ze swoich zdolności imitacyjnych i podrabia głos radnego (zna go prywatnie). Zadaniem aktora jest nakłonienie przez telefon wiceprezydenta do potwierdzenia nielegalnego układu, w którym radny ma otrzymać pierwsze miejsce na liście wyborczej w zamian za odstapienie od blokowania zamknięcia teatru, mającego otworzyć drogę do jego przebudowy w centrum hotelowe. Plan udaje się wyśmienicie, a nagrana rozmowa służy do szlachetnego w swoim celu szantażu, który powstrzyma władze miasta przed zamknięciem teatru. Trudna do przeoczenia duma Jerzego z wykonanego zadania - żartobliwie nazywa je on swoja , pierwszą premierą dnia" (za chwilę zaczyna nowy spektakl na deskach teatru) - nadaje scenie charakter delikatnej drwiny $\mathrm{z}$ aktorstwa opartego na perfekcyjnym naśladowaniu.

Obie wspomniane sceny z udziałem Jerzego wpisuja się w oczywisty porządek akcji odcinka serialu, w którym nieco poważniejsze rozstrzygnięcia przeplatają się z rozluźniającymi atmosferę żartami. Jeśli jednak spojrzymy na momenty, w których pojawia się Jerzy, jak na całościowy obraz pewnego typu aktorstwa, będziemy mogli wskazać aspekty pozwalające przybliżyć się do konceptu aktorstwa zadaniowego. Najbardziej wyrazistym przykładem aktorstwa, którego celem jest wykonanie wyznaczonego zadania, jest oczywiście prowokacja, w jakiej aktor wykorzystał swoje wyjątkowe zdolności imitacyjne. Dzięki tej scenie możemy łatwo uświadomić sobie, w jaki sposób sztuka aktorska staje się narzędziem realizacji różnych celów. Podobne zdolności naśladowcze są wykorzystywane na scenie teatralnej, choć jednocześnie są one często piętnowane jako rodzaj sztuki niskich lotów. Umiejętność podrobienia czyjegoś wizerunku wzbudza podziw, ale równocześnie zamyka możliwości dostrzeżenia relacji, w jaką aktor wchodzi z przedstawiana postacia. Taki rodzaj recepcji sztuki pozostaje więc w praktyce jednowymiarowy.

Aktorstwo zadaniowe nie ogranicza się, rzecz jasna, do prostej imitacji. Zadania stworzenia pewnego typu postaci, uruchomienia określonych emocji czy zbudowania pożądanej relacji z inną postacią przedstawienia mają także swój wymiar kreatywny. W moich próbach uchwycenia specyfiki aktorstwa tego typu przejdę jednak od razu do drugiego bieguna skali i zestawię zaprezentowana przez Jerzego sztukę imitacji z tym, co pokazał kilka scen wcześniej przed reżyserką Richter w czasie przesłuchania. Jak wcześniej wspomniałem, Richter nie widzi wybitnego aktora w swoim spektaklu, choć wyraża szacunek dla jego drogi twórczej. Kilka scen później docenia grę starszej aktorki w czasie prowadzonej przez siebie próby. Czego zatem wybitna reżyserka oczekuje od swoich aktorów? Na tak postawione pytanie 
nie potrafię udzielić odpowiedzi. Fragmenty gry aktorów są zbyt krótkie, aby pokusić się o charakterystykę systemu ich gry. Jedyną wyrazistą różnicą pomiędzy obiema sytuacjami jest to, że Jerzy po pierwszym sygnale niechęci reżyserki wobec jego krótkiego występu natychmiast proponuje, iż „może jeszcze inaczej...”. Starsza aktorka jest natomiast tak zdeterminowana, że jej próba wydaje się jedyną z możliwych i natychmiast trafia w oczekiwania Richter, zyskując jej aprobatę. Takie rozwiązanie scenariuszowe można odczytać, rzecz jasna, jako dość prosty zabieg retoryczny, który wzmacnia w odbiorcach przekonanie, że porozumienie, do jakiego dochodzi pomiędzy aktorką a reżyserka, wykracza poza właściwy dobór środków aktorskich i realizuje się w przestrzeni głębszej, o charakterze wymykającym się zewnętrznym przejawom. Kiedy jednak pogodzimy się z tym, że twórcy serialu Artyści nie odkryją przed nami tajemnicy metody pracy wielkiej Richter, musimy przyznać, iż talent Jerzego jest równie ulotny i trudny do opisania. To w końcu wielki aktor, zarówno jako postać w serialu, jak i grająca ją osoba. Czego zatem możemy dowiedzieć się z serialu Artyści o aktorze zadaniowym, który obok genialnej zdolności imitacji potrafi tworzyć także nieuchwytne w swym geniuszu szkice postaci? Kluczową kwestią zbliżenia się do tajemnicy, jak można rozumieć aktorstwo zadaniowe, pozostaje w tym przypadku gotowość Jerzego do „spróbowania inaczej”. Jerzy, który dysponuje szerokim wachlarzem możliwości aktorskich, jest gotowy przedstawiać kolejne propozycje, niedajace się sprowadzić do prostej taksonomii repertuaru emploi lub nawet znacznie bardziej dynamicznego i szerszego porządku charakterów. Występ Jerzego jest zbyt krótki, aby na jego podstawie dało się nakreślić jakaśs całościową koncepcję postaci czy nawet stylu gry, a może chociażby uchwycić postawę emocjonalną. Istotą kolejnych propozycji, jakie gotów jest przedstawiać aktor zadaniowy, pozostaje jednak domniemanie, że stanowią one pewną spójna, przewidywalną koncepcję gry, którą aktor będzie mógł kontynuować. $\mathrm{W}$ tym sensie są one zamknięte $\mathrm{w}$ ramach pewnego domniemanego repertuaru środków. Używam pojęcia „domniemanego”, ponieważ naiwnością sprzeczną z doświadczeniem teatralnym byłoby twierdzenie, że aktor zadaniowy, czyli w pewnym przybliżeniu aktor teatru tradycyjnego, porusza się $\mathrm{w}$ ramach niezmiennego repertuaru środków wyrazu. W procesie prób wiele założeń dotyczących koncepcji roli często radykalnie się zmienia; rola nie zawsze pozostaje też jednorodna w swoim rozwoju już po premierze. Rzecz jednak w tym, że na każdym etapie rozwoju roli lub w momencie zmian jej koncepcji aktor wychodzi z nowymi propozycjami lub podąża za sugestiami reżysera, co oznacza, że przyjęte ostatecznie rozwiązania opierają się na wyborze realizującym regułę „albo tak, albo tak”. Na deklarację: „mogę też inaczej” odpowiadamy przecież pytaniem: „czyli jak?”. Rola wprawdzie ewoluuje, zmienia się w konfrontacji z innymi 
postaciami, często zaskakuje nieoczekiwanymi rozwiązaniami, wszytko to jednak zamyka się w domniemanych granicach wyboru sposobu gry, jaki dokonał się w trakcie prób. Podkreślę po raz kolejny, że granice, o których piszę, pozostają w sferze domniemania. Spójność gry aktora zadaniowego pozostaje bowiem zawsze oceniana przez pryzmat naszych interpretacji poszczególnych fragmentów przedstawienia oraz w części subiektywnych wyobrażeń o dopasowaniu poszczególnych rodzajów ekspresji. Dynamika tak rozumianej roli zamyka się zatem zawsze w pewnych prezałożeniach, które zostają wypracowane w czasie prób, z drugiej zaś strony powstają w umysłach odbiorców w wyniku procesów rozumienia oglądanego przedstawienia.

W przypadku aktora performatywnego charakterystyczne sa jego otwartość, zdolność do uruchamia wciąż nowych procesów tak w sobie, jak i w partnerach, z którymi znajduje się na scenie. Aktor performatywny nie jest oczywiście wolny od pewnych założeń dotyczących roli, która gra. Kluczowe dla zarysowania różnicy pomiędzy oboma typami aktorstwa pozostaje jednak kryterium wiarygodności. W przypadku aktorstwa tradycyjnego jest nim umiejętność utrzymania się w roli (wykonania nakreślonego zadania); nawet jeśli w pewnych momentach będzie to oznaczało przekroczenie ustalonych wcześniej granic, to przekroczenie to powinno być świadome i w pewien sposób znaczące lub estetycznie istotne. Aktor performatywny buduje swoją wiarygodność za sprawą swojej otwartości i przede wszystkim gotowości do uruchamiania procesów, których źródłami pozostają przede wszystkim on sam i jego żywa obecność na scenie.

Naszkicowane powyżej różnice pomiędzy źródłami wiarygodności gry aktora zadaniowego i performatywnego nie wyczerpują opisu cech, które dałoby się wyprowadzić z konceptów obu typów aktorstwa. Celem niniejszego artykułu nie jest jednak ostateczne doprecyzowanie odrębności dookreślających dwa typy współczesnego aktorstwa, ale przyjrzenie się temu, w jaki sposób te dwa pojęcia oraz powiązane $\mathrm{z}$ nimi praktyki aktorskie rezonuja z nowa polską dramaturgia. Deskryptywne i enumeratywne ujęcia cech obu typów aktorstwa bardzo szybko ujawniają swoje niedoskonałości, które ostatecznie muszą być wyjaśniane za pomoca przykładów doprecyzowujących zakres ich stosowania. Aby to zrozumieć, wystarczy przywołać opisany już powyżej przykład zadania, które wykonuje postać z serialu Artyści, Jerzy, podrabiając głos radnego w celu zdobycia informacji koniecznych do demaskacji spisku przeciwko teatrowi. Jego popis aktorski zdaje się leżeć na drugim końcu wzniosłej sztuki teatru. Tymczasem „sztuczka” wybitnego aktora ma przecież także cechy wskazywane jako specyficzne dla nowoczesnego aktorstwa performatywnego. W rozmowie ze spiskującym przeciwko Teatrowi Popularnemu wiceprezydentem miasta Jerzy musi uruchomić swoje zdolności improwizatorskie i jednocześnie podporządkować całość swojego 
występu kryterium sprawczości. Właśnie ze względu na takie przenikanie cech jednego typu aktorstwa do jego drugiego rodzaju proste wyliczenia cech okazują się niezadowalające. Dlatego w dalszych rozważaniach przyjmuję perspektywę, w której dążenie do zamkniętego zbioru badań i reguł zostanie zastapione refleksją nad dynamicznym i zmiennym polem wzajemnego oddziaływania pojęć oraz praktyk związanych z aktorem performatywnym i nowa polską dramaturgią. Od systemowego ujęcia powiązania pomiędzy aktorstwem performatywnym a nowa polską dramaturgia bardziej produktywne wydają się „studia przypadków”, które w swojej różnorodności ujawniaja potencjalne drogi wyjścia z zaklętego kręgu afirmacji i subwersywności, ograniczającego nie tylko potencjał twórczy, lecz także możliwości wytwarzania nowych modeli życia społecznego.

Zestawienie aktorstwa performatywnego z twórczością obejmującą nową polską dramaturgię wydaje się dość oczywiste zarówno w wymiarze historycznym, jaki i opisowym. Nowa polska dramaturgia, podobnie jak aktorzy performatywni, już od dłuższego czasu poszukuje form twórczości, które przekraczając klasyczne modele sztuki, nie ograniczają się do ich negacji lub krytyki. Zewnętrzne podobieństwa obu form twórczości nie prowadza jednak do głębszego zrozumienia ich wartości i perspektyw. Dopiero przyjrzenie się przykładom realizacji teatralnych wybranych tekstów pozwala zrozumieć, w jaki sposób gra aktora performatywnego rezonuje z tekstem dramaturgicznym, otwierając przed sztuką teatru nowe horyzonty.

Jednym z bardziej oczywistych przykładów powiązania tekstu z aktorami jest przedstawienie Michała Borczucha Wszystko o mojej matce ${ }^{1}$. Tekst został bowiem napisany przez Tomasza Śpiewaka na podstawie intymnych zwierzeń reżysera oraz jedynego męskiego bohatera przedstawienia Krzysztofa Zarzeckiego. Związek opowiadanej historii z życiem jej odtwórców nie ułatwia jednak zadania aktorowi i reżyserowi, który - choć na krótko - również pojawia się na scenie. Odtworzenie samego siebie na deskach teatru wydaje się zarazem naiwne i fałszywe. Dlatego główny bohater nie przedstawia się na scenie jako Krzysztof Zarzecki, który zrzuciwszy maski swoich wcześniejszych teatralnych ról, daje widzom sposobność ujrzenia prawdziwego człowieka, stojacego do tej pory za tak wieloma lubianymi i docenianymi rolami. Takie obnażenie nie jest ani możliwe, ani pożądane. Ostatecznie tekst, który wypowiada Zarzecki, to nie jego zwierzenia, ale słowa napisane lub co najmniej uporządkowane przez Tomasza Śpiewaka. $\mathrm{Z}$ drugiej strony nie sposób zdystansować się wobec historii tak mocno zakorzenionej w prywatnym i zarazem niezwykle dojmującym doświadczeniu

${ }^{1}$ Wszystko o mojej matce, dramaturgia: Tomasz Śpiewak, reżyseria: Michał Borczuch, premiera: Teatr Łaźnia Nowa, 22.04.2016. 
aktora. Zarzecki zmaga się zatem z tekstem, który wygłasza, a także ze słowami wypowiadanymi przez aktorki w zastępstwie jego matki. Z jednej strony jego sytuacja przypomina doświadczenie tradycyjnego aktora, którego głównym zadaniem jest utrzymanie tworzonej fikcji, mogącej w każdej chwili runąć. Z drugiej strony jego uwikłanie w proces, w którym bierze udział, jest znacznie bardziej złożone, gdyż nie poddaje się prostym rozstrzygnięciom prawdziwy-fikcyjny, wiarygodny-zakłamany, szczery-udawany. Nikt przecież nie odważy się krzyknaćc: „ależ pan fałszuje!” w sytuacji, w której aktor porusza się w przestrzeni bliskiej jego osobistej, realnej intymności. Ten szczególny rodzaj mało wyrazistego przesunięcia, nie tyle dekonstruującego wcześniejsze porządki, ile raczej podającego w wątpliwość ich istotność, stawia odbiorcę w sytuacji, w której wszelkie znane mu sposoby nadawania oglądanemu dramatowi znaczenia stają się nieadekwatne. Przy czym sytuacja wydaje się permanentna w odróżnieniu od stanu literatury przejściowej, która oczekuje na wypracowanie nowych ram interpretacyjnych dla ewoluującej sztuki. Permanentny stan zagrożenia, a może jedynie niepewności, odpowiada performatywnemu charakterowi sztuki aktorskiej, której często wymienianą cechą jest stała gotowość do inicjowania nowych procesów twórczych. Od tak ogólnych diagnoz istotniejsze wydaje mi się jednak to, w jaki sposób sytuacja wykreowana przez podmiotową obecność na scenie źródła przedstawianej historii wpływa na tekst przygotowany przez dramaturga $\mathrm{w}$ jego wymiarze czastkowym.

W swojej recenzji ze spektaklu Witold Mrozek $^{2}$ podkreśla, że w tekście Śpiewaka nie ma łatwego sentymentalizmu. Czy jednak ocena recenzenta faktycznie odnosi się do samego tekstu, czy do jego wykonania na scenie? Wystarczy rzucić okiem na pierwsze frazy wypowiadane przez aktorki grające matkę, aby zorientować się, że ich słowa to sprawna, acz dość oczywista stylizacja potocznej mowy prostych kobiet z fabryki Miracullum. Niezgrabność składniowa połączona z nadmierna skłonnościa do ujawniania swoich dość naiwnych refleksji o życiu wydaje się niczym innym jak jednym ze sposobów wprowadzania widzów w przestrzeń łagodnej uczuciowości, bliskiej temu, co nazywamy sentymentalizmem. Tekst napisany przez Śpiewaka nie stanowi jednak zadania dla aktorek, które ogranicza się do rozwinięcia jego potencjalnych walorów estetycznych i znaczeniowych. Aktorki wypowiadają bowiem swoje kwestie w obecności syna kobiety, który z ich pomocą stara się przywołać pamięć swojej matki. Powaga i odpowiedzialność, która odczuwaja, sprawiaja, że lekko humorystyczne frazy przygotowane dla nich przez Śpiewaka przełamują się

${ }^{2}$ Witold Mrozek, Świetny spektakl „Wszystko o mojej matce”. Co taczy Borczucha z Almodóvarem?, wyborcza.pl, https://wyborcza.pl/7,75410,19982317,swietny-spektakl-wszystko-o-mojej-matce-co-laczy-borczucha.html (dostęp: 20.07.2021). 
przez ich nadwymiarową uważność na obecność Krzysztofa Zarzeckiego i Michała Borczucha. Aktorki nie migrują więc pomiędzy swoją podmiotowością a rola, co stanowi często wyróżnianą cechę aktorek performatywnych. Znacznie ważniejsza w przedstawieniu Borczucha jest bowiem zdolność do nieprzerwanego odczuwania obecności obu synów matek granych przez aktorki. Ta zdolność stanowi dopełnienie przypisywanej aktorkom performatywnym umiejętności wytwarzania poczucia silnej obecności na scenie. W odniesieniu do tekstu stworzonego przez Śpiewaka nadaje mu charakter głębokiego wzruszenia, które wydaje się trudne do osiagnnięcia za pomoca środków aktorstwa zadaniowego.

Nieco inny obszar doświadczenia kontaktu ze sztuką teatralną można dostrzec w kolejnym znakomitym przykładzie tekstu wpisującego się w ramy nowej polskiej dramaturgii, mianowicie w Hamlecie ${ }^{3}$ Marcina Cecki, wyreżyserowanym przez Krzysztofa Garbaczewskiego. Niezwykle bogata w różnorodne rozwiązania nowoczesnego dramatopisarstwa wersja historii Hamleta, którą przygotował Cecko, pozwala opisać szeroki wachlarz cech charakterystycznych dla tekstów pisanych dzisiaj dla teatru. W ramach mojego zainteresowania zależnościami pomiędzy aktorstwem performatywnym a nową polską dramaturgią skupię się jednak na wybranym elemencie przedstawienia, którym jest wprowadzenie do tekstu, a następnie na deski teatru trzech aktorów grających jedną postać Hamleta. Takie rozczłonkowanie postaci budzi zazwyczaj pytania o jego funkcję. Z lektury kolejnych recenzji analizujących spektakl Garbaczewskiego widać wyraźnie, że próby przypisania poszczególnym wersjom Hamleta pewnych wyróżnionych cech nie prowadzą do pogłębionej refleksji. Aneta Kyzioł wyjaśnia w swojej recenzji na łamach „Polityki” ${ }^{4}$, ze Hamletów jest trzech ze względu na trzy wymiary spektaklu, w ramach których rozgrywa się dramat: psychologiczny, polityczny i społeczny. Z tak przedstawionego rozdziału niewiele jednak wynika dla rozumienia sztuki Garbaczewskiego. Znacznie bliższe uchwycenia walorów tego przedstawienia są Olga Katafiasz i Joanna Targoń. Pierwsza recenzentka zauważa, że w „Hamlecie pomieszczą się co najmniej trzy hi-

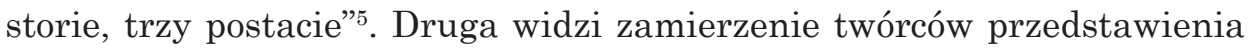
jeszcze szerzej. Już na początku zwraca uwagę na to, że Cecko i Garbaczewski szukają sposobu na Hamleta, odrzucając dobrze nam znane klucze psychologiczny czy polityczny i równocześnie rezygnując z dążenia do własnej fabuły. Według Targoń Hamlet, którego oglądamy na deskach Starego

${ }^{3}$ Hamlet, dramaturgia: Marcin Cecko, reżyseria: Krzysztof Garbaczewski, premiera: 13.06.2015.

${ }^{4}$ A. Kyzioł, Hamlet roz(s)trojony, „Polityka” 23 czerwca 2015.

${ }^{5}$ O. Katafiasz, Pułapka nadmiaru, teatralny.pl, https://teatralny.pl/recenzje/pulapka-nadmiaru,1141.html (dostęp: 20.07.2021).

145 Po co dramaturgowi aktor performatywny? 
Teatru, to spektakl „z całym bagażem interpretacji i myślenia o teatrze”6. Dramat Szekspira - jak na jedno z największych arcydzieł sztuki dramatopisarstwa - staje się swoistym opus magnum samego teatru. Okazuje się sztuką niezwykle pojemna, w której mieści się cały świat.

W jaki jednak sposób mają tak rozumianą sztukę grać aktorzy odtwarzający główną postać? Różni, mówiący różnymi, choć czasem zazębiającymi się językami? Co sprawia, że tworzone przez trzech wybitnych aktorów role w ramach jednej postaci potrafią unieść ciężar dramaturgii bez wchodzenia ze sobą w konfrontację? W celu wyjaśnienia tego doświadczenia teatralnego chciałbym przywołać analizę, która pochodzi z pracy magisterskiej Małgorzaty Maciejewskiej, napisanej na krakowskiej PWST. Autorka dokonuje analizy postaci Hamleta z przedstawienia Garbaczewskiego w kontekście teorii afektywności. Jej analiza jest interesująca w kontekście niniejszych rozważań, ponieważ pozwala dostrzec mechanizm poszerzenia dyskursywnego aspektu dramatu o Hamlecie o wymiar performatywnej obecności aktora na scenie. Ten mechanizm można wyprowadzić z dwóch konceptów pracy. Pierwszy, o charakterze teoretycznym, opisuje doświadczenie afektu w kategoriach śladu. Autorka pracy wyjaśnia, że w momentach zaafektowania „towarzyszy nam często nieokreślone uczucie rozpoznania, nieraz nawet epifanii" ", którego źródła nie da się ostatecznie zidentyfikować. W dalszej części pracy przywołuje moment z przedstawienia Cecki i Garbaczewskiego, w którym grający jednego z Hamletów Bartosz Bielenia wypowiada słowa Ofelii. Kim zatem jest Bielenia, ubrany w tym momencie w koronkowa sukienkę, z twarzą pokrytą nieudolnie wykonanym makijażem, nerwowo palacy papierosa? W swojej analizie Maciejewska podkreśla dość oczywisty fakt, że taki zabieg prowadzi do zachwiania możliwości identyfikacji z postacią. Znacznie ciekawsze sąjednak jej późniejsze refleksje. Zwraca w nich uwagę na nieoczekiwane powinowactwo Ofelii i Hamleta, które wprowadza do odbioru perspektywę queerową i jednocześnie „zdejmuje z tej relacji dyskurs mizoginistyczny". Źródłem tych przeobrażeń w recepcji spektaklu są nie tylko znaczenia nadbudowujące się nad nietypowym kostiumem aktora czy przypisaniem mu kwestii Ofelii. Androgeniczna cielesność aktora, która zaznacza się w jego motoryce, sprawia, że nie sposób rozdzielić poszczególnych elementów jego gry na te przynależne Hamletowi lub Ofelii. Krytyczna refleksja rozpływa się tym samym w afektywnym rodzaju współodczuwania

${ }^{6}$ J. Targoń, Hamlet przekręcony, gazeta.pl, https://krakow.wyborcza.pl/krakow/7,35796,18129193,stary-teatr-hamlet-przekrecony-recenzja.html (dostęp: 20.07.2021).

${ }^{7}$ M. Maciejewska, Teatr jako medium bezpośredniego kontaktu w perspektywie teorii afektywności, praca magisterska, Państwowa Wyższa Szkoła Teatralna, Kraków 2016.

${ }^{8}$ Ibidem. 
z aktorem/postacią, który zgodnie z zarysowanym wcześniej konceptem stanowi jedynie afektywny ślad w pamięci: kim jest kobieta?, kim jest mężczyzna?, może jest kimś jeszcze? Ślad, który przyczynia się do poczucia bliskości z postacia, nie pozwala jednak ani na prowadząca do zrozumienia identyfikację, ani na dystans pozwalający przyjąć postawę krytyczna. Materialne ciało drugiej osoby nigdy nie daje się do końca przeniknąć ani w pełni opisać.

Podobny efekt bliskości, oparty na rozmyciu pola odniesień za sprawą zaafektowania postacią Hamleta, daje się zauważyć w roli Krzysztofa Zarzeckiego, znanego z gry, w której podmiotowość aktora przenika się z graną rola. W dramacie Cecki ta kwestia zostaje stematyzowana w dialogu Modżewskiej i Swinarskiego, włączonym w historię Hamleta:

Modżewska:

W czerwcu przyszedł do mnie Pan Zarzecki i oświadczył, że chce grać Hamleta i że chce porozmawiać o Hamlecie

Swinarski

Świetny wybór, Zarzecki ostatnio jest w bardzo dobrej kondycji

W dalszej części rozmowy Swinarski i Modżewska dochodzą do wniosku, że nie sposób dobrze zagrać Hamleta, interpretując go. Dlatego „Hamletów musi być trzech”. Jak jednak pozbyć się interpretacji? Czy trzech Hamletów to przypadkiem nie trzy interpretacje tej postaci? Rozwiązanie tej zagadki zostaje zasugerowane $\mathrm{w}$ przytoczonej powyżej wymianie zdań pomiędzy Modżewską i Swinarskim, od której zaczyna się ich dialog. Wspomniany w nim Zarzecki, który chce grać Hamleta, zgodnie ze słowami Swinarskiego „znajduje się w bardzo dobrej kondycji”. Ten metateatralny żart, wpleciony w dramat przez Ceckę, niesie ze sobą potencjalnie poważniejsze konsekwencje w odbiorze spektaklu. Wspomnienie o kondycji Zarzeckiego nie musi ograniczać się jedynie do oceny jego chwilowych możliwości, przywołuje bowiem jednocześnie cały potencjał i historię jego aktorskich dokonań. W ten sposób horyzont, jaki wyznacza rola Hamleta, zostaje poszerzony o nasz stosunek do Zarzeckiego jako aktora, nasze wspomnienia ukształtowane na gruncie wcześniejszych spotkań z tym aktorem w teatrze, a także wiedzę lub tylko wyobrażenia o nim jako osobie prywatnej. Tak ogromny konglomerat odczuć nie daje się poskładać w żaden wizerunek postaci i tym samym pozostawia widza w sytuacji, w której odbiór granej przez Zarzeckiego roli wpisuje się raczej w obszar naszych afektywnych intuicji aniżeli rozumienia.

Trzecim odtwórca Hamleta w przedstawieniu Garbaczewskiego jest Roman Gancarczyk. Starszy od dwóch pozostałych aktorów, wywodzi swój 
rodowód z Hamleta-Maszyny Heinera Millera. Jednak krytyczny wymiar tekstu Millera ponownie rozmywa się za sprawa wydobycia na pierwszy plan cielesności aktora. Myślę tu przede wszystkim o scenie, w której w centrum uwagi zostaje postawiona twarz aktora mówiącego słowa monologu. Gancarczyk wypowiada swój tekst, patrząc prosto w kamerę, z której obraz trafia na olbrzymich rozmiarów ekran. Ogromne powiększenie wydobywa każdą zmarszczkę, pozwala zajrzeć w zawężone źrenice, daje wgląd niemal w pory jego skóry. Paradoksalnie jednak wcale nie ułatwia to analizowania mimiki aktora. Zbyt duża bliskość obrazu uniemożliwia bowiem zajęcie dobrze oswojonej w tradycyjnym teatrze postawy podglądacza. Trudno jest analizować czyjaśs grę, kiedy ta osoba patrzy nam w oczy z odległości bliższej niż ta, do której mogliśmy przywyknąć w naszym fizykalnym świecie.

Podobnie jak w przypadku dwóch pozostałych aktorów rola, którą widzowie chcieliby wyłuskać z gry, rozpływa się pod naporem wdzierającej się w przestrzeń recepcji cielesności wraz z jej materialnym i afektywnym wymiarem. Powstający w ten sposób efekt bliskości wywołuje w widzu wrażenie czegoś znanego, czego jednak nie sposób odnaleźć w tak pojemnym doświadczeniu, jakim jest doświadczanie cudzego ciała obecnego tu i teraz, które otwiera naszą uważność na ginące w mrokach przeszłych historii ślady naszej afektywnej pamięci. Za sprawą przesunięcia głównej linii dramatu w stronę afektywności reguły dyskursywnego odbioru przestają być elementem wiodącym. Splot gry trzech różnych aktorów w roli Hamleta konstytuuje się za sprawą afektów, bez potrzeby konfrontowania przedstawionych przez nich propozycji. Grając Hamleta, wreszcie „nie trzeba interpretować" tej postaci. Tymczasem perspektywa aktora zadaniowego implikuje pytania, które nieuchronnie prowadzą do dookreślania interpretacji głównego bohatera Szekspirowskiego dramatu: jakie znaczenie ma prywatne doświadczenie Zarzeckiego w kreowaniu Hamleta?, w jakim celu Hamlet mówi słowami Ofelii?, jak grać Hamleta, kiedy jest się od niego dwukrotnie starszym?

Te pytania sa oczywiście jedynie arbitralnie wybranymi przykładami. Przywołuję je jednak po to, aby uwidocznić, że aktorstwo oparte na realizowaniu zadań zamyka horyzonty, które otwiera przed nową dramaturgia perspektywa performatywna. Porównywanie wieku, wyglądu czy doświadczeń aktorów prowadzi nieuchronnie do konfrontacji ich warunków i zasobów ludzkiego doświadczenia z domniemaną rolą lub rolami. Wspomniany na początku tego artykułu Krzysztof Dracz w roli Jerzego z serialu Artyści zapewne potrafiłby zagrać i młodego, i starego Hamleta, a także podrobić niedbały styl gry Zarzeckiego. Tym samym jednak z refleksji nad sztuką i ludzkim życiem Cecki uczyniłby zabawna, acz mało znacząca anegdotkę. 
Ostatnim przedstawieniem, któremu chciałbym się przyjrzeć, jest Sprawa Gorgonowej ${ }^{9}$ Joli Janiczak w reżyserii Wiktora Rubina. Grająca główną rolę w tym przedstawieniu Marta Ścisłowicz wydaje się stać na przeciwnym biegunie do tego, na którym znalazł się Zarzecki grający siebie samego w przedstawieniu Wszystko o mojej matce. Choć Marta Ścisłowicz na scenie prezentuje nam postać słynnej przedwojennej morderczyni Rity Gorgonowej, to porusza się $\mathrm{w}$ ramach tekstu, który w gruncie rzeczy został napisany dla niej. Podmiotowość aktorki wydaje się w tym spektaklu nieodróżnialna od tekstu, który ona wypowiada, a cielesna obecność na scenie zdaje się uwzględniona w słowach napisanych dla niej przez Janiczak. Trudno zresztą byłoby przyglądać się niuansom i przesunięciom performatywnego wymiaru gry aktorki, która na scenie uwalnia nadludzką wręcz siłę i energię. W serii swoich pierwszych monologów, które są odpowiedziami na pytania sądu, Ścisłowicz rąbie leżący na przodzie sceny twardy głaz ciężkim dżaganem. W kolejnych scenach aktorka udowadnia, że nadzwyczajny wysiłek fizyczny i bezkompromisowe oddanie swojego ciała wymogom przedstawienia nie odbierają mocy wypowiadanemu tekstowi, przeciwnie - napędzaja go, czyniąc, jak pisze w swojej recenzji Marcin Kościelniak, spektaklem nie krytycznym, ale terrorystycznym ${ }^{10}$. W innej recenzji Paweł Soszyński zwraca uwagę na to, że inscenizacja tekstu Janiczak należy do zadań arcytrudnych. „Okiełznać rwacy nurt słów, zapanować nad ich narracja - dramat Janiczak to wyzwanie: utrzymać się na tekście, nie stracić równowagi, dotrzeć do końca kolejnej fali. Zadanie arcytrudne" ${ }^{11}$. Ścisłowicz nie ma jednak problemu z tym zadaniem. Przecież zostało ono stworzone przez dramaturżkę specjalnie dla niej i choć pod naporem słów „scena zdaje się pękać w szwach"12, Ścisłowicz nawet na chwilę nie traci równowagi. Jeśli więc prawdą jest, że - jak pisze Kościelniak - spektakl nie oferuje odbiorcom oczyszczenia, „lecz eksponuje nie dające się wchłonąć resztkę i brud”, to efekt ten zostaje uzyskany za sprawa zwycięskiej konfrontacji aktorki z językiem, który tylko ona potrafi ujarzmić.

Doceniając rolę aktorki w uwydatnieniu znaczeń tekstu Janiczak, nie chciałbym wywoływać wrażenia, że ten tekst staje się pełny dopiero w realizacji Ścisłowicz. Przeciwnie, Sprawa Gorgonowej w lekturze odkrywa przed czytelnikiem wiele sensów, które giną w przedstawieniu. Kluczowa dla mo-

${ }^{9}$ Sprawa Gorgonowej, dramaturgia: Jola Janiczak, reżyseria: Wiktor Rubin, premiera: Stary Teatr w Krakowie, 28.03.2015.

${ }^{10}$ M. Kościelniak, Spektakl terrorystyczny, e-teatr, https://e-teatr.pl/spektakl-terrorystyczny-a196414 (dostęp: 20.07.2021).

${ }^{11}$ Język rozkłada każde ciało, e-teatr.pl, https://e-teatr.pl/jezyk-rozklada-kazde-cialo-a197199 (dostęp: 20.07.2021).

${ }^{12}$ Ibidem. 
jego wywodu jest hipoteza, że zabójcze dla dzieła Janiczak mogłyby okazać się aktorstwo zadaniowe i takież rozumienie przedstawienia teatralnego. Przyjrzyjmy się jednemu z oczywistych założeń spektaklu Janiczak i Rubina, które przyjmuje, że przyzwyczajeni do modelu detektywistycznego akcji widzowie muszą pogodzić się z tym, że w życiu prosta odpowiedź na pytanie: „kto zabił?" nie odkrywa wszystkich tajemnic i nie prowadzi do ostatecznego zrozumienia wydarzeń. Próba zobrazowania tej prawdy prowadzi jednak do banału, co najłatwiej dostrzec w recenzjach, które próbują analizować dzieła nowej polskiej dramaturgii z lekceważeniem naddatku dodawanego przez performatywne aktorstwo. Tak spoglądający na współczesny polski teatr recenzenci nie dostrzega wspomnianego naddatku, owego brudu w przypadku Sprawy Gorgonowej, który oferują widzowi zarówno performatywne aktorstwo, jak i współczesny polski dramat.

Podkreślając wagę aktorstwa performatywnego dla rozwoju dramaturgii, nie chciałbym sugerować, że jest to jedyna droga dla nowej sztuki teatru. Uważam jednak, że istnieje istotny i tym samym konieczny do rozważania i opisywania zwiazek pomiędzy nowymi formami aktorstwa a nowym polskim dramatem. Przedstawienie Janiczak i Rubina stanowi wyjątkowo klarowny dowód na performatywną moc tekstu dramatycznego. Władza nad tekstem przygotowanym przez dramaturga dla teatru, a często dla konkretnych aktorów, nie ogranicza się jednak do jego perfekcyjnego zrozumienia i opanowania. Przeciwnie, jest raczej konfrontacją na każdym etapie rozwoju przedstawienia. Dramaturgia aktorstwa performatywnego rodzi się zatem z permanentnej konfrontacji z tekstem, którego wykonanie nigdy nie stanowi zakończonego zadania. Dlatego właśnie pewien rodzaj swobody w konstrukcji wielu współczesnych tekstów dramaturgicznych nie oznacza dekonstrukcji zastanych modeli, ale dopasowanie do potencjału aktorstwa performatywnego. Specyfika gry aktora performatywnego nie ogranicza się zatem do ustanawiania jego wzmożonej obecności na scenie, na co zwraca się uwagę w przypadku performera. Znacznie istotniejsza, moim zdaniem, cechą aktora performatywnego jest jego nadzwyczajna uważność, która pozwala mu nie tyle pogłębić lekturę tekstu dramaturgicznego, co poszerzyć ją o nowe aspekty doświadczenia sztuki teatru. Permanentna konfrontacja $\mathrm{z}$ tekstem pozostaje zawsze otwarta na nowe rozwiązania lub rozumienie przez publiczność. Jednocześnie szczególna umiejętność uważności wobec otaczającego świata pozwala aktorowi performatywnemu konfrontować się także z innymi aspektami przedstawienia, takimi jak ciało czy podmiotowy wymiar grających role aktorów.

Żeby jednak ostatecznie dookreślić specyfikę aktorstwa performatywnego w ramach nowej polskiej dramaturgii, do pojęcia konfrontacji trzeba dodać jeszcze ideę zaufania. Ostatecznie aktor zadaniowy również ma dar 
postrzegania otaczającej go rzeczywistości - także tej, która nie wpisuje się w ramy konwencji teatralnych - i reagowania na nią. Głównymi celami tych umiejętności pozostają jednak awangardowe z natury prowokacje, postmodernistyczny krytycyzm lub wreszcie zdolność odbudowywania fikcji teatralnej, która czasem niknie pod naporem przypadkowych błędów czy nieprzewidzianych zdarzen. Tymczasem aktor performatywny korzysta z aktorskich zdolności improwizacji oraz konfrontacji z materią sztuki i życia w celu poszerzenia doświadczenia teatralnego. Jego podmiotowa obecność na scenie, nieoczekiwana bliskość powiększonej twarzy na ekranie czy wreszcie nadzwyczajna energia, która bierze w karby całość przedstawienia, raczej inicjuja procesy afektywnego i mentalnego przeżywania, aniżeli je domykaja. Aby jednak widz wyłączył wyuczoną skłonność do interpretowania wszystkiego, co go otacza, aktor musi wyzbyć się postawy lęku wobec tekstu, którego znaczenia nie zawsze i nie do końca przenoszą się na publiczność, którego sensy ustalone na próbach moga zostać zgubione w nieuważnej grze, który koniecznie trzeba skomentować, aby uniknąć naiwności lub utrwalania szkodliwych modeli życia. Taką przestrzeń zaufania buduje wiele współczesnych polskich dramatów. Próba ich interpretacji w tradycyjnym ujęciu wzbudza ponownie podejrzliwość u odbiorców. Dlatego właśnie polska dramatugia potrzebuje aktora performatywnego.

\section{BIBLIOGRAFIA}

Katafiasz O., Putapka nadmiaru, teatralny.pl, https://teatralny.pl/recenzje/pulapka-nadmiaru,1141.html (dostęp: 20.07.2021).

Kościelniak M., Spektakl terrorystyczny, e-teatr, https://e-teatr.pl/spektakl-terrorystyczny-a196414 (dostęp: 20.07.2021).

Kyzioł A., Hamlet roz(s)trojony, „Polityka” 23 czerwca 2015.

Mrozek W., Świetny spektakl „Wszystko o mojej matce”. Co łaczy Borczucha z Almodóvarem?, wyborcza.pl, https://wyborcza.pl/7,75410,19982317,swietny-spektakl-wszystko-o-mojej-matce-co-laczy-borczucha.html (dostęp: 20.07.2021).

Soszyński P., Język rozkłada każde ciało, https://e-teatr.pl/jezyk-rozklada-kazde-cialo-a197199 (dostęp: 20.07.2021).

Targoń J., Hamlet przekręcony, gazeta.pl, https://krakow.wyborcza.pl/krakow/7,35796, 18129193,stary-teatr-hamlet-przekrecony-recenzja.html (dostęp: 20.07.2021).

Wojciech Baluch - dr hab., prof. Uniwersytetu Jagiellońskiego w Katedrze Performatyki. Ukończył studia teatrologiczne w Instytucie Polonistyki UJ. W 1988 roku przebywał na półrocznym stypendium Fulbrighta na uniwersytecie SUNY at Buffalo w USA. Jego praca doktorska była poświęcona procesowi interpretacji w ujęciu kognitywnym. Był inicjatorem i współorganizatorem serii konferencji dla młodych naukowców, poświę-

151 Po co dramaturgowi aktor performatywny? 
conych problematyce związanej z teatrem i dramatem. Habilitowany w 2012 roku na podstawie książki Po-między-nami. Staby dyskurs w polskim dramacie wspótczesnym. Autor antologii dramatu Polska dramatyczna 3 wydanej w 2014 roku oraz wstępu do tejże: Antologia polskiego dramatu niekanonicznego. Obecnie zajmuje się współczesna dramaturgią w szerokim kontekście teorii humanistycznych. Jest kierownikiem międzyuczelnianej grupy badawczej, która zajmuje się różnymi wymiarami społeczno-artystycznymi z perspektywy różnorako rozumianej dramaturgii. ORCID: 0000-0002-1115-5636. Adres e-mail: <wojciech.baluch@uj.edu.pl>.

Wojciech Baluch - PhD (dr hab.), professor of the Jagiellonian University, Department of Performance Studies. Graduated in theater studies from the Institute of Polish Studies at the Jagiellonian University. In 1988, he was on a six-month Fulbright scholarship at the SUNY University in Buffalo, USA. His doctoral dissertation was devoted to the cognitive interpretation process. Initiator and co-organizer of a series of conferences for young scientists devoted to issues related to theater and drama. Gained his habilitation degree in 2012 on the basis of the book Po-Miedzy-Nami. Weak discourse in Polish contemporary drama. Author of the anthology of the drama Polska Dramatyczna 3, published in 2014, and the introduction to the same: Anthology of Polish non-canonical drama. Currently, he deals with contemporary dramaturgy in the broad context of humanistic theories. Head of an inter-university research group that deals with various socio-artistic dimensions from the perspective of variously understood dramaturgy. ORCID: 0000-0002-1115-5636. E-mail address: <wojciech.baluch@uj.edu.pl>. 